\title{
ANALISIS PENERAPAN PSAK 102 ATAS PEMBIAYAAN MODAL INVESTASI MURABAHAH PADA BAITUL MAAL WAT TAMWIL (BMT) NURUL FALAH SAWANGAN DEPOK
}

\author{
Imam Sofi'i \\ Fakultas Ekonomi Universitas Pamulang \\ imam_mpd@yahoo.co.id
}

\begin{abstract}
Abstrak
Baitul Maal Waat Tamwil (BMT) Nurul Falah adalah sebagai lembaga keuangan syariah yang berkembang pesat dari segi perkembangan keuangan dan nasabahnya yang cukup tinggi. BMT Nurul Falah melakukan pembiayaan Murabahah dimana pembiayaan ini sangat diminati oleh masyarakat karena mudah dalam pengajuan dan mudah dalam penerapannya. Pembiayan modal investasi ini guna memperlancar usaha nasabah tanpa di sertai adanya jaminan dalam pengajuan pembiayaannya. Penerapan Akad Murabahah di BMT Nurul Falah pada pembiayaan modal investasi tanpa jaminan tambahan ini dapat dikatakan sesuai dengan syariah karena dalam praktek pelaksanaan akad murabahah sesuai dengan PSAK 102. Penelitian ini menggunakan metode penelitian deskriptif kualitatif, dimana penelitian ini bertujuan untuk memahami bagaimana penerapan PSAK 102 dalam pembiayaan modal investasi murabahah. Dalam pengumpulan data peneliti menggunakan metode observasi, wawancara dan dokumentasi.
\end{abstract}

Kata Kunci : Penerapan, Pembiayaan, Modal Investasi, Akad Murabahah, PSAK 102

\section{PENDAHULUAN}

Tata peraturan ekonomi yang terkandung didalam Al-Qur'an dan AlHadits, memiliki suatu system ekonomi yang diatur secara hati-hati melalui nilai-nilai komprehensif, yaitu setiap aktifitas transaksi roda ekonomi harus didasarkan pada sifat jujur, adil, toleransi dan suka sama suka, baik yang dilakukan dalam aktifitas perdagangan, berbagi atau dalam semua aspek yag terkait ekonomi. Hal ini dapat dilihat indikatornya dari tunjangan sistem barter (material dan manfaat), baik melalui jual dan beli, kepentingan, pegadaian, kerja sama dan lain-lain. Agama Islam sangatlah lentur dengan memberikan kebebasan seluas mungkin dalam aktifitas transaksi ekonomi (peristiwa karena tidak melanggar nilai-nilai Islam secara umum) yang memberitahu mereka untuk selalu beraktifitas secara dinamis dalam berupaya menciptakan transaksi secara mudah dan dengan perubahan yang valid dalam 
setiap waktu dan segala tempat. Selain itu, seiring dengan meningkatnya kesadaran umat Muslim di Indonesia adalah terhadap hukum Islam.

Dalam kurun waktu tahun terakhir studi, pemikiran-pemikiran dan diskusi -diskusi tentang ekonomi Islam telah menjadi lebih sering, dan ini memiliki pengaruh besar pada sistem ekonomi Islam pada umumnya dan lembaga keuangan Islam pada khususnya. Sebagaimana kita ketahui bersama, bahwa lembaga keuangan adalah salah satu media yang dimanfaatjan untuk menegakkan aturan-aturan ekonomi.

Demikian juga dengan lembaga keuangan syariah, di mana lembagalembaga ini menjadi salah satu media dalam menegakkan aturan-aturan Islam yang akan memberikan kontribusi baik untuk mencapai tujuan sosial-ekonomi masyarakat, adanya regulasi bisnis yang lebih baik dan bebas dari praktik penipuan. Pengaruh ini dapat dilihat dengan meningkatnya jumlah lembagalembaga keuangan syariah dalam bentuk bank atau non-bank. Di Indonesia, pada tahun 2010 telah ada 25 Lembaga Perbankan Komersial Syariah, 100 BPR Syariah, perusahaan yang ikut serta menerbitkan saham dan sukuk yang telah menarik perhatian pasar, sehingga penerbitan sukuk negara bahkan telah dilakukan. terjual kurang dari 4000 BMT telah menyebar ke seluruh Indonesia. Munculnya lembaga keuangan syariah (LKS) merupakan cermin kesadaran umat Islam akan hukum Islam.

Dalam beberapa tahun terakhir studi, pemikiran dan diskusi terhadap ekonomi Islam telah menjadi lebih intens, dan ini memiliki pengaruh besar pada sistem ekonomi Islam secara umum dan badan lembaga keuangan Islam khususnya. Sebagaimana kita ketahui bersama, lembaga keuangan yaitu salah satu media yang dimanfaatkan untuk menegakkan aturan ekonomi

Peraturan Sistem Akuntansi No. 102 adalah kegiatan akuntansi yang melihat bagaimana proses pencatatan terhadap produk pembiayaan yang menggunakan sistem jual beli dari proses transaksi yang dilakukan antara pihak-pihak yang terlibat menjadi sistem akuntansi yang digunakan di lembaga syariah. Sejiring dengan hal tersebut, pembiayan investasi dalam produk pembiayaan pada BMT Nurul Falah Depok adalah pembiayaan dengan akad 
Murabahah. Berdasarkan data yang diperoleh dari, BMT Nurul Falah Depok ditemukan bahwa diantara empat produk pembiayaan yang ditawarkan oleh BMT Nurul Falah Depok yaitu akad Mudharabah, Musyarakah, Murabahah dan qardh. bentuk pembiayaan yang paling banyak diminati oleh nasabah adalah jenis pembiayaan akad murabahah.

\section{METODE PENELITIAN}

Dalam penelitian ini peneliti menggunakan penelitian deskriptif kualitatif. Oleh karena itu metode dalam hal ini yang digunakan penulis yaitu metode deskriptif kualitatif. Metode deskriptif kualitatif adalah suatu metode penelitian yang banyak digunakan oleh para peneliti yang bertujuan untuk memaparkan suatu peristiwa. Metode ini seperti yang disampaikan oleh Sugiyono (2011) “ penelitian desktiptif adalah sebuah penelitian yang bertujuan untuk memberikan atau menjabarkan suatu keadaan atau fenomena yang terjadi saat ini dengan menggunakan prosedur ilmiah untuk menjawab masalah secara aktual".

Dari uraian di atas dapat peniliti simpulkan bahwa penelitian deskriptif adalah suatu cara/metode yang digunakan untuk menjelaskan, menginterpretasikan suatu peristiwa/fenomena. Oleh sebab itu, penulis berasumsi bahwa metode deskriptif ini sesuai dengan penelitian yang dilakukan oleh peneliti. Karena dalam penelitian ini, peneliti berusaha mendeskripsikan sebuah masalah yang terdapat dalam pembiayan investasi pada BMT Nurul Falah Depok.

Untuk memperoleh data penulis menggunakan dua data yang digunakan yaitu macam-macam dan sumber data : yaitu jenis data kualitatif dan kuantitatif. Data kualitatif yaitu berupa gambaran umum perusahaan dan struktur organisasi. Dan kuantitatif berupa informasi mengenai dokumen yang digunakan. Sedangkan sumber data yaitu dari data primer dan data sekunder. Data primer diperoleh dengan observasi langsung ke objek penelitian yaitu di BMT Nurul Falah Depok. Untuk data sekunder penulis mengambil catatan dan dokumen. Sedangkan metode pengumpulan data dengan menggunakan 
wawancara, observasi dan studi pustaka untuk mencari refrensi buku, website dan penelitian terdahulu yang relevan.

\section{HASIL PENELITIAN DAN PEMBAHASAN}

\section{Sistem pembiayaan modal investasi BMT Nurul Falah}

Pengertian Investasi menurut Kamaruddin Ahmad, yaitu menempatkan uang dengan tujuan untuk memperoleh tambahan atau profit tertentu pada uang tersebut. Definisi modal investasi menekankan pada penempatan uang. Adapun tujuan investasi ini untuk mendapat untung. Ini terkait erat dengan berinvestasi di pasar modal.

Jadi penulis mensimpulkan Investasi adalah suatu aktivitas yang berkaitan dengan upaya untuk menarik sumber daya (dana) yang digunakan untuk saving/menyimpan barang modal saat ini dan barang modal yang akan diperoleh oleh perputaran produk baru di masa depan.

Sedangkan Murabahah adalah suatu akad transaksi penjualan barang atau jasa dengan menyebutkan harga perolehan/modal awal dan keuntungan yang disepakati antara penjual dan pembeli. Pembiayaan Murabahah BMT Nurul Falah adalah pembiayaan berdasarkan akad jual beli antara BMT dan nasabah. BMT memberikan modal usaha kepada nasabah sebesar harga pokok ditambah dengan keuntungan margin yang disepakat. Investasi BMT Nurul Falah adalah para anggota nasabah yang bernabung.

Penerapan Akuntasi Pembiayaan Murabahah BMT Nurul Falah Telah Sesuai Dengan PSAK 102

\section{Pencatatan (pengakuan dan pengukuran)}

Tabel 3.1 pencatatan (pengakuan dan pengukuran) berdasarkan PSAK 102

\begin{tabular}{|c|c|c|c|c|}
\hline No & Aspek & Keterangan & Aplikasi & Ket. \\
\hline 1 & $\begin{array}{l}\text { Biaya } \\
\text { perolehan }\end{array}$ & $\begin{array}{llr}\text { Pada saat } & \text { perolehan, aset } \\
\text { murabahah } & \text { diakui } & \text { sebagai } \\
\text { persediaan } & \text { sebesar } & \text { biaya } \\
\text { perolehan } & & \end{array}$ & $\begin{array}{lr}\begin{array}{l}\text { Persediaan } \\
\text { berdasarkan }\end{array} & \text { biaya, } \\
\text { yaitu semua } & \text { biaya } \\
\text { yang timbul sampai } \\
\text { barang } & \text { siap } \\
\text { digunakan atau dijual. }\end{array}$ & Sesuai \\
\hline
\end{tabular}




\begin{tabular}{|c|c|c|c|c|}
\hline 2 & $\begin{array}{l}\text { Pengukuran } \\
\text { asetmurabah } \\
\text { ah }\end{array}$ & $\begin{array}{l}\text { Akad murabahah dengan } \\
\text { pesanan mengikat, maka: } \\
\text { a.Sebuah. dinilai berdasarkan } \\
\text { biaya; } \\
\text { b. jika suatu aset mengalami } \\
\text { penurunan sebab kadaluwarsa, } \\
\text { rusak, atau kondisi lain yang } \\
\text { sebelum diserahkan kepada } \\
\text { pelanggan, penurunan nilai } \\
\text { akan diakui sebagai beban dan } \\
\text { otomatis akan mengurangi nilai } \\
\text { aset }\end{array}$ & \begin{tabular}{|lr} 
BMT & hanya \\
menerapkan & \\
murabahah & pesanan \\
dan & sifatnya \\
mengikat nasabah \\
untuk membeli .aset \\
murabahah di nilai \\
sebesar & biaya \\
perolehan. &
\end{tabular} & Sesuai \\
\hline & & $\begin{array}{l}\text { murabahah tanpa pesanan } \\
\text { maka: } \\
\text { a. Sebuah akan dinilai } \\
\text { berdasarkanbiaya } \\
\text { diperoleh atau neto yang dilihat } \\
\text { dr realisasi, mana yang lebih } \\
\text { rendah; } \\
\text { b. jika nilai realisasi bersih } \\
\text { lebihrendah daribiaya } \\
\text { perolehan, selisihnya akan } \\
\text { diakui sebagai kerugian }\end{array}$ & - & \\
\hline 3 & $\begin{array}{l}\text { Potongan } \\
\text { pembelian }\end{array}$ & $\begin{array}{l}\text { Diskon nasabah/pembelian pada } \\
\text { aset murabahah akandiakui } \\
\text { sebagai: } \\
\text { a. Pengurang terhadap } \\
\text { perolehan aset murabahah, jika } \\
\text { terjadi sebelum dilakukannya } \\
\text { akad murabahah; } \\
\text { a. liabilitas kepada nasabah, jika } \\
\text { transaksi tersebut setelah } \\
\text { akad murabahah dan sesuai } \\
\text { dengan akad yang telah } \\
\text { disepakati maka akan } \\
\text { menjadi hak nasabah; } \\
\text { b. penaambahan margin } \\
\text { murabahah, jika itu terjadi } \\
\text { setelah perjanjian akad } \\
\text { murabahah dan sesuai kontrak } \\
\text { maka diskon milik BMT; atau } \\
\text { b. pendapatan dari operasional } \\
\text { lain, jika dilakukan setelah } \\
\text { akad dan tidak ada }\end{array}$ & $\begin{array}{l}\text { Jika BMT } \\
\text { memberikan diskon , } \\
\text { maka potongan itu } \\
\text { hak pelanggan. Jika } \\
\text { pengurangan terjadi } \\
\text { setelah kontrak maka } \\
\text { distribusi karya } \\
\text { dilakukan } \\
\text { berdasarkan } \\
\text { perjanjian yang telah } \\
\text { diterbitkan } \\
\text { dalam kontrak }\end{array}$ & $\begin{array}{l}\text { Belum } \\
\text { sesuai }\end{array}$ \\
\hline
\end{tabular}




\begin{tabular}{|c|c|c|c|c|}
\hline & & $\begin{array}{l}\text { kesepakatan dalam akad } \\
\text { tersebut. }\end{array}$ & & \\
\hline 4 & $\begin{array}{l}\text { Piutangmura } \\
\text { bahah }\end{array}$ & $\begin{array}{l}\text { Piutangmurabahah akan diakui } \\
\text { sebesar biaya perolehan aset } \\
\text { ditambah laba yang telah } \\
\text { disepakati. Pada akhir } \\
\text { pelaporan keuangan, piutang } \\
\text { murabahah dinilai sebanyak } \\
\text { nilai neto, yaitu saldo terutang } \\
\text { dikurangi penyisihana } \\
\text { kerugiann. }\end{array}$ & 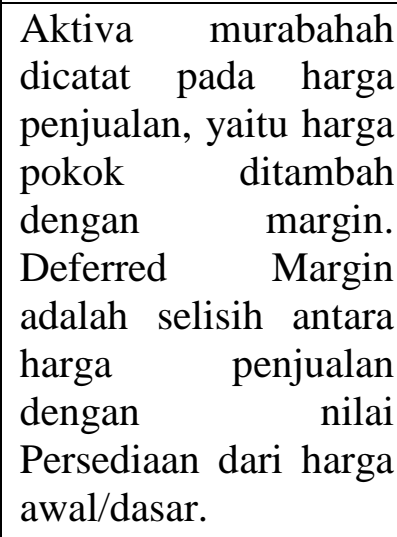 & Sesuai \\
\hline \multirow[t]{2}{*}{4} & \multirow[t]{2}{*}{$\begin{array}{l}\text { Keuntungan } \\
\text { murabahah }\end{array}$} & $\begin{array}{l}\text { pada saat terjadinya penyerahan } \\
\text { asset apabila dilakukan secara } \\
\text { tunai atau dengan cara } \\
\text { tangguh yang tidak lebih dari } \\
\text { satu tahun }\end{array}$ & $\begin{array}{l}\text { Keuntungan di akui } \\
\text { saat penyerahan aset } \\
\text { murabahah }\end{array}$ & Sesuai \\
\hline & & $\begin{array}{l}\text { selama periode kontrak sesuai } \\
\text { tingkat risiko dan usaha dalam } \\
\text { melakssanakan manfaat ini } \\
\text { untuk transaksi sulit lebih dari } \\
\text { satu tahun. Maka dapat } \\
\text { menggunakan cara berikut: } \\
\text { a. Keuntungan akandiakui saat } \\
\text { penyerahan aset murabahah } \\
\text { b. Profit diakuiproporsional } \\
\text { dengan besarankas yang } \\
\text { berhasil ditagih dari piutang } \\
\text { murabahah }\end{array}$ & & \\
\hline 5. & $\begin{array}{l}\text { Diskon } \\
\text { pelunasan }\end{array}$ & $\begin{array}{l}\text { Pelunasan piutang murabahah } \\
\text { yang diberikan kepada } \\
\text { pelanggan / pembeli yang dapat } \\
\text { melunasi tepat waktu atau lebih } \\
\text { cepat akan diakui sebagai } \\
\text { pengurang } \\
\text { murabahah }\end{array}$ & \begin{tabular}{|lr} 
BMT & dapat \\
memberikan & \\
potongan & (termasuk \\
muqasah) & apabila \\
nasabah : & \\
a. & melakukan \\
pelunasan & tepat \\
waktu, atau & \\
b. melunasi piutang \\
murabahah sebelum \\
jatuh tempo, r \\
yang besar & dan \\
jumlahnya & sesuai \\
ketentuan & dan \\
kebijakan Bank
\end{tabular} & Sesuai \\
\hline
\end{tabular}




\begin{tabular}{|c|c|c|c|c|}
\hline & & $\begin{array}{l}\text { Metode potongan pelunasan } \\
\text { piutang murabahah: } \\
\text { a. diberikan pada saat } \\
\text { pembayaran, yaitu penjual akan } \\
\text { mengurangi piutang serta } \\
\text { keuntungan murabahah; atau } \\
\text { b. diberikan setelah } \\
\text { pembayaran, yaitu, penjual } \\
\text { menerima pembayaran } \\
\text { kembalipiutang dari pembeli } \\
\text { dan kemudian membayar } \\
\text { diskon pembayaran kepada } \\
\text { pembeli. }\end{array}$ & & \\
\hline 6. & $\begin{array}{l}\text { Potongan } \\
\text { angsuran }\end{array}$ & $\begin{array}{l}\text { Potongan angsuran murabahah } \\
\text { diakui sebagai berikut: } \\
\text { a. jika potongan/diskon } \\
\text { disebabkan oleh pelananggan / } \\
\text { pembeli yang membayar tepat } \\
\text { waktu, akan diakui } \\
\text { sebagaipengurang k } \\
\text { keuntunganmurabahah; } \\
\text { b. Apabila disebabkan karena } \\
\text { penurunan kemampuan } \\
\text { pembeli untuk membayar, } \\
\text { maka akan diakui sebagai } \\
\text { beban }\end{array}$ & $\begin{array}{lr}\text { Potongan angsuran di } \\
\text { berikan } & \text { kepada } \\
\text { nasabah } & \text { yang } \\
\text { membayar } & \text { tepat } \\
\text { waktu } & \text {,akan } \\
\text { mengurangi } & \\
\text { keuntungan } & \\
\text { murabahan } & \text { dan } \\
\text { adanya permintaan } \\
\text { dari nasabah atas } \\
\text { ketidakmampuan } \\
\text { membayar di akui } \\
\text { sebagi beban }\end{array}$ & Sesuai \\
\hline 7. & Denda & $\begin{array}{l}\text { Denda diberikan jika } \\
\text { nasabah/pembeli lalai dalam } \\
\text { melaksanakan kewajibannya } \\
\text { sebagaimana yang disepakati } \\
\text { dalam kontrak, dan denda yang } \\
\text { diterima dan diakui sebagai } \\
\text { bagian dari dana kebajikan }\end{array}$ & $\begin{array}{l}\text { Dana Qardhul Hasan } \\
\text { (Kebajikan) } \\
\text { merupakan } \\
\text { kewajiban yang } \\
\text { harus segera } \\
\text { direalisasikan } \\
\text { untuk kegiatan } \\
\text { sosial, yang dapat } \\
\text { disalurkan secara } \\
\text { langsung bagi yang } \\
\text { membutuhkan atau } \\
\text { secara tidak langsung } \\
\text { melalui yayasan atau } \\
\text { lembaga sosial. }\end{array}$ & Sesuai \\
\hline
\end{tabular}


Tabel 3.2 penyajian perlakuan akuntansi berdasarkan PSAK 102

\begin{tabular}{|c|c|c|c|c|}
\hline 8. & penyajian & $\begin{array}{l}\text { Piutang atau aktiva } \\
\text { murabahah dinyatakan } \\
\text { sebesar nilai realisasi neto, } \\
\text { yaitu saldo } \\
\text { piutangmurabahah akan } \\
\text { dikurangi penyisihan } \\
\text { kerugian. }\end{array}$ & $\begin{array}{l}\text { Pelunasan angsuran oleh } \\
\text { nasabah yang nilainya } \\
\text { sebesar jumlah pokok } \\
\text { pembiayaan (piutang) di } \\
\text { tambah potongan margin } \\
\text { yang telah di } \\
\text { perhitungkan atau } \\
\text { dengan arti lain saat } \\
\text { penyeleseian BMT hanya } \\
\text { mengurangi pendapatan } \\
\text { keuntungan }\end{array}$ & Sesuai \\
\hline 9 & & $\begin{array}{l}\text { Marjin murabahah yang } \\
\text { ditangguhkan disajikan } \\
\text { hanya sebagai pengurang } \\
\text { (contra account) untuk } \\
\text { piutang murabahah }\end{array}$ & & \\
\hline 10 & & $\begin{array}{l}\text { Beban murabahah } \\
\text { tangguhan disajikan } \\
\text { sebagai pengurang utang } \\
\text { murabahah. }\end{array}$ & & \\
\hline
\end{tabular}

Tabel 3.3 pengungkapan perlakuan akuntansi bedasarakan PSAK 102

\begin{tabular}{|c|c|c|c|c|}
\hline 11 & pengungkapan & $\begin{array}{l}\text { Pengungkapan BMT dalam } \\
\text { hal-hal yang terkait dengan } \\
\text { transaksi murabahah, akan } \\
\text { tetapi tidak terbatas pada: } \\
\text { a. harga yang didapatkan } \\
\text { aset murabahah; } \\
\text { b. penunjukan pesanan } \\
\text { pada murabahah } \\
\text { berdasarkan pesanan } \\
\text { sebagai kewajiban atau } \\
\text { tidak; dan }\end{array}$ & $\begin{array}{l}\text { Kebijakan akuntansi } \\
\text { yang ada di BMT Nurul } \\
\text { Falah Depok juga } \\
\text { mengungkapkan } \\
\text { transaksi-transaksi } \\
\text { murabahah seperti } \\
\text { perolehan aset } \\
\text { murabaha,persediaan } \\
\text { piutang murabahah } \\
\text {,margin murabahah ,dan } \\
\text { lainnya. }\end{array}$ & sesuai \\
\hline
\end{tabular}




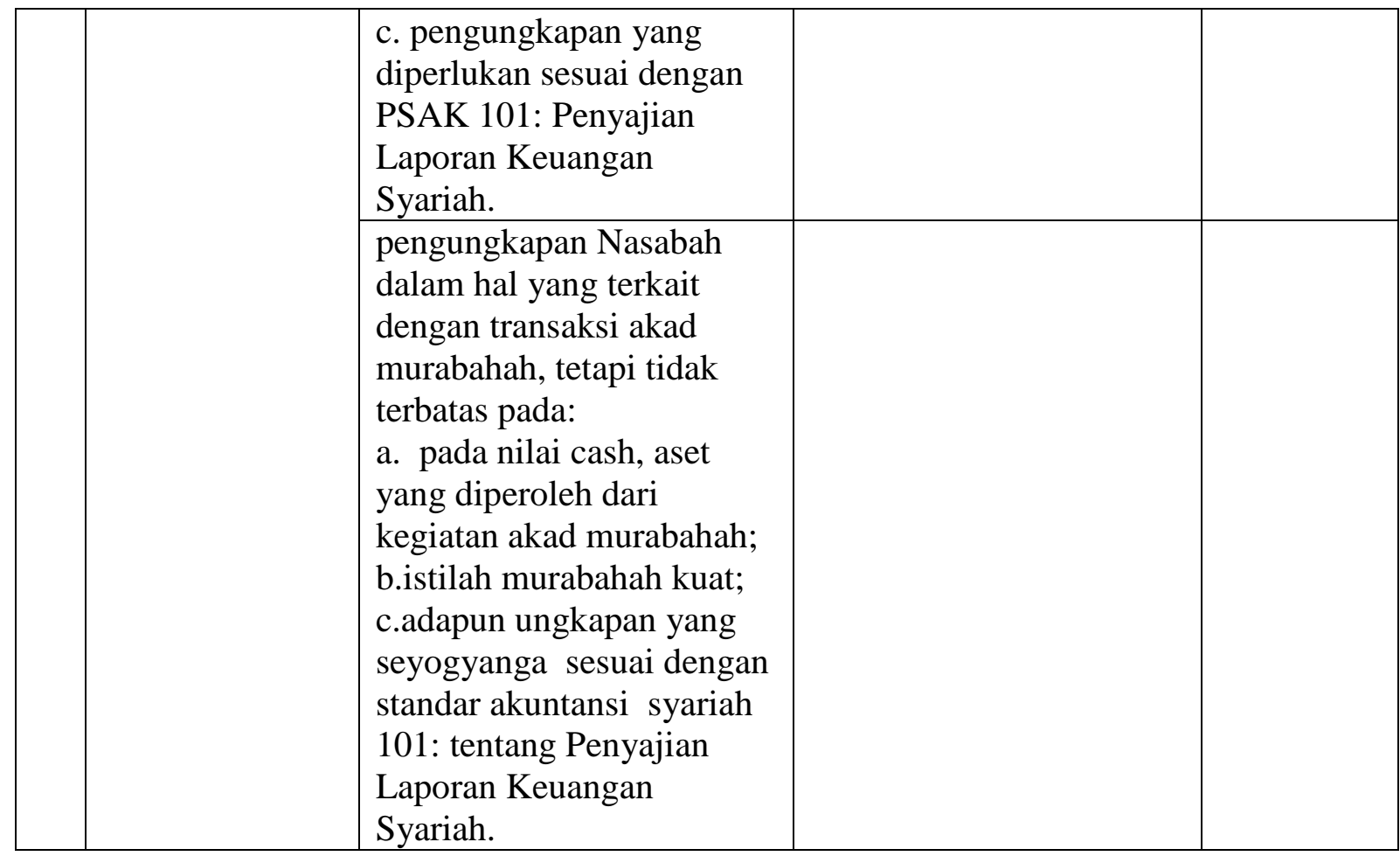

\section{Simulasi Akad Pembiayan Modal Investasi Murabahah}

Tanggal 01-07-2016 BMT Nurul Falah menyutujui pemberian fasilitas murabahah oleh Sumiyati yang bergerak di bidang dagang dengan sepakatan sebagai berikut :

Harga pokok : Rp.1.000.000.-

Uang muka : 10\% dari harga barang

Pembiayaan oleh BMT : Rp.900.000

Margin keuntungan : 20\% dari pembiayaan BMT

Harga jual : harga barang plus margin jangka waktu 3 bulan

Biaya Andminitrasi : 1\% dari harga peroleh gerobak baso.

Berikut ini Jurnalnya :

- Set akad murabahah disepakati

\begin{tabular}{|lcc|}
\hline Keterangan & Debet & kredit \\
\hline Piutang murrabahah & Rp. 1.180 .000 & \\
\hline Aset murabahah & Rp. 1.000 .000 \\
\hline Margin yang ditangguhkan & Rp. 180.000 \\
\hline
\end{tabular}


- Pembayaran uang muka

\begin{tabular}{|lcc|}
\hline Keterangan & Debet & Kredit \\
\hline Kas / tabungan Sumiyanti & Rp.100.000 & \\
\hline Uang muka & & Rp.100.000 \\
\hline
\end{tabular}

Perhitungan persukutuan keuntungan diperbadingan margin dengan biaya pendapatan

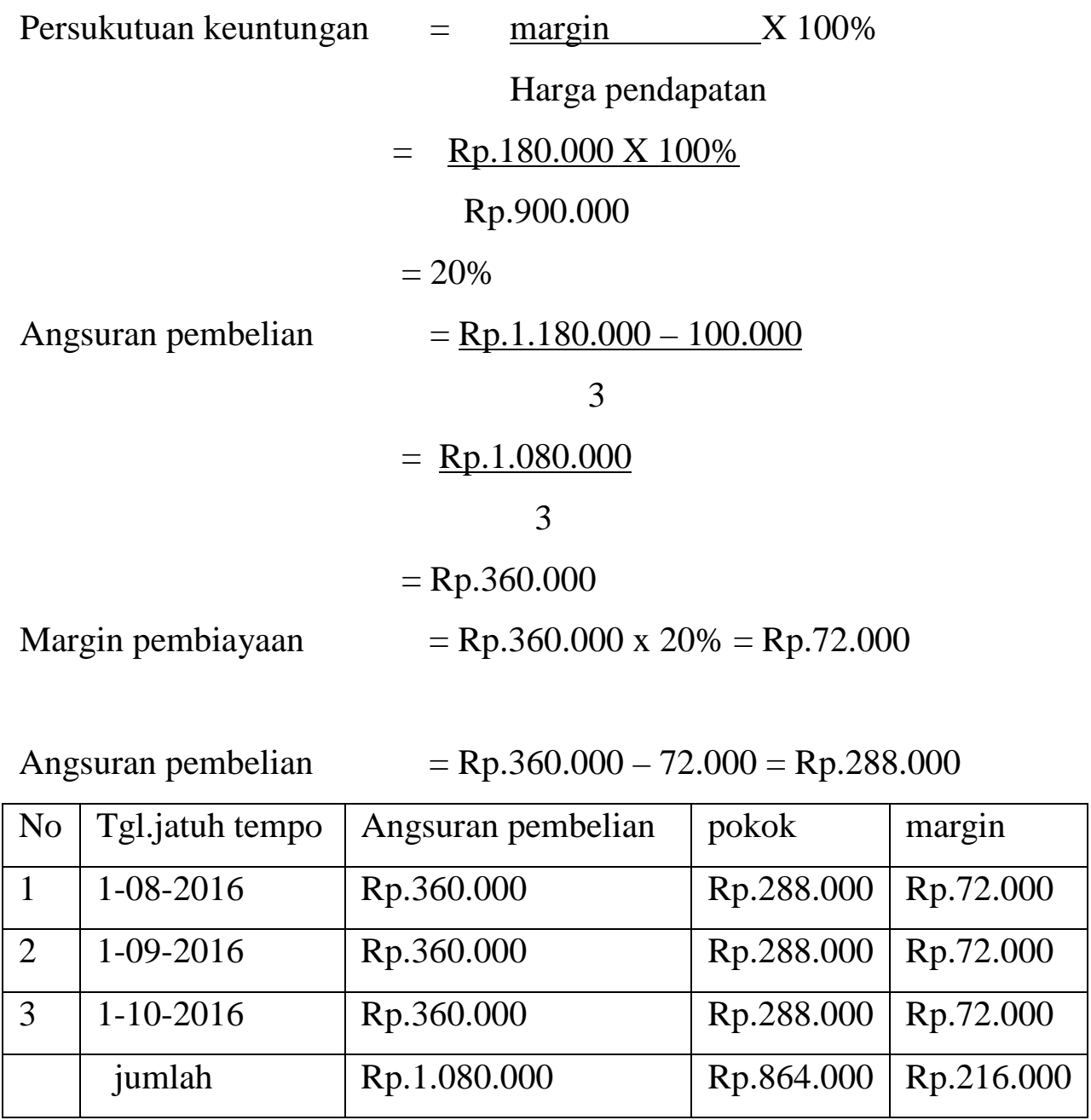


- Surat BMT membeli aset murabahah

a) Secara tunai

\begin{tabular}{|l|l|l|}
\hline Keterangan & Debet & Kredit \\
\hline Aset murabahah & Rp.1.000.000 & \\
\hline Kas & & Rp.1.000.000 \\
\hline
\end{tabular}

b) Secara kredit

\begin{tabular}{|l|l|l|}
\hline Keterangan & Debet & Kredit \\
\hline Aset murabahaha & Rp1.000.000 & \\
\hline Utang & & Rp.1.000.000 \\
\hline
\end{tabular}

- Pelunasan

\begin{tabular}{|l|l|l|}
\hline keterangan & Debet & Kredit \\
\hline Utang & Rp.1.000.000 & \\
\hline Kas & & Rp.1.000.000 \\
\hline
\end{tabular}

- Pecatatan biaya admistrasi

\begin{tabular}{|l|l|l|}
\hline keterangan & Deket & Kredit \\
\hline Kas & Rp.1.000.000 & \\
\hline pendapatan & & Rp. 1.000 .000 \\
\hline
\end{tabular}

\section{SIMPULAN}

Berdasarkan pembahasan dari data-data yang sudah di jelaskan di bab sebelumnya maka dapat di ambil kesimpulan sebagai berikut :

1. Penerapan akad Murabahah pada BMT Nurul Falah Depok yaitu berupa dana pinjaman investasi yang dipinjamkan oleh pihak BMT kepada nasabah serta adanya biaya margin atau keuntungan yang didapatkan oleh BMT Nurul Falah dengan menggunakan pembiayah akad Murabahah yang diberikan pihak BMT kepada nasabah untuk mempermudah melakukan usaha yang berbasis sesuai dengan syariah. Prosedur BMT Nurul Falah 
dalam menerapkan akad Murabahah telah sesuai PSAK 102, iini dapat dilihat dari laporan keuangannya

2. Perlakuan akuntansi pembiayaan modal investasi,bahwa kebijakan akuntansi yang ada di BMT Nurul Falah juga mengungkapkan transaksitransaksi murabahah seperti perolehan aset murabaha,persediaan piutang murabahah ,margin murabahah, dan lainnya.

\section{REFERENSI}

Basrowi dan Suwandi, 2008. Memahami Penelitian Kualitati. Jakarta: Rineka Cipta

Buchari Alma dan Donni Juansa. 2014. Manajemen Bisnis Syariah. Bandung: Alfabeta.

Djuwaini, Dimyauddin, 2010. Pengantar Fiqih Muamalah, Yogyakarta: Pustaka Pelajar

Heri Sudarsono. 2015. Bank dan Lembaga Keuangan Syariah edisi 4. Jakarta: Ekonosia.

Huda, Nurul, dkk, 2010. Lembaga Keuangan Islam, Jakarta: Kencana Prenada Media Group

Ismail. 2011. Perbankan Syariah. Jakarta: Kencana.

Ridwan , Muhammad. 2004. Manajemen Baitul Maal wat Tamwil. Yogyakarta: UII Press

Rizal Yaya. 2014. Akuntansi perbankan syariah edisi 2. Jakarta: Salemba Empat.

Srinurhayati dan Wasilahh. 2105. Akuntansi Syariah Di Indonesia edisi 4. Jakarta: Salemba Empat.

Sri Rezeki, F.Y. 2013. Akad Pembiayaan Muraahah dan Praktik pada PT. BSM Cabang Manado. Lex Privatum, Vol. 1, No. 2, Hal. 19-31.

M. Nur Rianto Al Arif. 2015. Pengantar Ekonomi Syariah. Pustaka Setia

Eka Wahyu Lestari, NIM.1123204016 Prosedur Analisis Pembiayaan Ibadah Haji Di Bri Syariah Purwokerto, Tugas Akhir. Sekolah Tinggi Agama Islam Negeri Purwokerto, 2014 